\title{
Bilingualism as the Medium of Educational Instruction: An Exploratory Study of Student and Teachers' Views in Lebanon
}

\author{
Nahla Nola Bacha ${ }^{1}$ \\ ${ }^{1}$ School of Arts and Sciences, Department of English, Lebanese American University, Lebanon \\ Correspondence: Nahla Nola Bacha, School of Arts and Sciences, Department of English, Lebanese American \\ University, Lebanon. E-mail: nbacha@lau.edu.lb
}

Received: March 10, 2019 Accepted: April 6, 2019 Online Published: May 20, 2019

doi:10.5539/ijel.v9n3p330 URL: https://doi.org/10.5539/ijel.v9n3p330

\begin{abstract}
Bilingualism as the medium of educational instruction in institutions has led to much controversy. The challenge, however, for policy makers is to address the issue of what languages are to be the medium of instruction and the place of the home and minority languages in EFL contexts as English becomes the lingua franca worldwide. Further, research has shown that bilingual students when compared to monolingual students perform better in academic institutions as they have developed higher cognitive skills required for learning. Although bilingualism as the medium of instruction has been researched and has become more common in institutions worldwide, it is under researched in L1 Arabic contexts especially in the Lebanese multilingual/cultural context from the student and teachers' point of view. This paper reports on an exploratory survey study of student and teachers' preferences in one English medium institution in Lebanon as to what language(s) they prefer to study in at both the pre and university levels. Main findings indicate that both students and teachers show a high preference for bilingualism as the medium of instruction at both the pre and university levels with English the priority medium. Implications and recommendations for future research are made.
\end{abstract}

Keywords: bilingualism, medium of instruction, EFL/ESL, curriculum, bilingual education, Lebanon

\section{Introduction}

\subsection{The Problem}

Over the past several decades, it has been debated as to the extent bilingual education is effective in mainstream classrooms at both the secondary (used interchangeably with high school in this study) and tertiary (used interchangeably with university in this study) educational institutions from different aspects such as language acquisition, teaching/learning, cultural awareness, identity and learner attitudes (Archila \& Truscott de Mejía, 2017; Baker \& Wright, 2017; Dewaele, Housen, \& Wei, 2003; García, Lin, \& May, 2017; Palfreymen \& van der Valt, 2017). Speaking more than one language, many argue, is necessary in today's global world as this opens wider career and educational opportunities and facilitates cross cultural communication (e.g., Jin \& Cortazzi, 1997; Jaumont, 2018; among others). Thus, it is claimed that it is necessary for educational institutions to meet the multi-literacy needs of students especially in light of the strong influence from monolingual medium proponents and their work on academic English which often does not take minority languages into account at university levels. Rong (2007, p. 9) highlighted the challenge that educational institutions need to address.

The language of instruction is the medium through which knowledge is transmitted during the educational process. Because of this, the issue of what language the teachers use when giving lectures and what language is used to compile the text materials they adopt becomes a core issue in educational development for any multiethnic, multilingual country.

\subsection{The Significance of the Problem}

Studies have shown that bilingualism has positive effects on developing the learner's high order cognitive skills (see Vygotsky, 1978 iconic work on zone of proximal development) which in turn has wide implications for students carrying out higher studies in bi/multilingual contexts. This is well noted by Marian and Shook (2012, p. 4).

The improvements in cognitive and sensory processing driven by bilingual experience may help a bilingual person to better process information in the environment, leading to a clearer signal for learning. 
Over the past several decades, there has been much debate on whether or not a bilingual education is of value (e.g., Sayigh, 1965; Frayha, 2004; Golash-Boza, 2005; Shaaban \& Ghaith, 1999; Zakharia, 2017). A bilingual education for many policy makers is not only becoming a prized priority at the pre university level but increasingly more so at the university level worldwide (Zakharia, 2017). Belhiah and Elhami's (2015) study on $500 \mathrm{~L} 1$ Arabic speakers and 100 instructors in six universities in the United Arab Emirates (UAE), Qatar, Kuwait, Bahrain, Oman, and Saudi Arabia found that students and teachers significantly preferred to study in both English and Arabic. The authors argue that with the students' low proficiency level in English, it is more efficient to have a biliteracy language policy as in this way the students would improve in English and at the same time be less frustrated in learning their subject matter. Additionally, this would preserve their national identity. They also suggest to have bilingual instructors as they would better understand the culture and background of the students and thus, they claim, offer more effective student learning. Bilingualism as the medium of instruction is still under researched and with globalism it has become important for educational institutions to make decisions as to what language or languages to adopt in the face of increasing bi/multilingualism worldwide. However, little research has been carried out at the pre and university levels in Lebanon from students and teachers' perspectives leaving a gap in this research field. The present study aims to explore the extent to which bilingualism as the medium of instruction is favored by both students and teachers, the stakeholders, at the pre and university levels in one English medium educational institution in Lebanon which would contribute to the body of knowledge in this field.

\subsection{Review of Literature}

\subsubsection{Bilingualism}

It is significant to understand how bilingualism is currently viewed and its relationship to a medium of instruction. Research in the 20th century indicates that, on the one hand, speaking in more than one language confuses the learner (Baker \& Wright, 2017) while on the other students speaking and studying in more than one language are 'smarter', have more developed cognitive skills, and can better process information from the environment and thus show more of an ability for learning than that of monolinguals (Bartolottie \& Marian, 2012; Bhattacharjee, 2012; Baker \& Wright, 2017; Dooly, 2007).

Spolsky (1978) had proposed a theory and model for bilingual education but at the same time highlighted its complexity and its dependency on certain factors and situations. However, political, economic and religious issues challenged colonialism and its implementation of English or French as a medium of instruction to the ousting of national languages as a kind of imperialism and power through indirect means which was met with disfavor in many countries worldwide (Orr \& Annous, 2018; Zakharia, 2009). Nevertheless, putting the non-linguistic factors aside, the world, and especially in Lebanon, has become even more bilingual and multilingual as people and students travel, and emigrate to seek better opportunities. It is not surprising that many researchers support a bilingual education. Golash Boza (2013) argues that a bilingual education has advantages over a monolingual education, and its advantages, especially for immigrant children, are far reaching in helping those limited in English to complete a university education.

\subsubsection{Bilingual Education}

To what degree bilingualism as the medium of instruction is effective has not been without debate. Recently, some studies have cautioned the fast-growing introduction of English as the medium of instruction (EMI) at all levels of education and in many countries worldwide (see Dearden, 2016). These studies point out that governmental language policies that 'impose' EMI seem to be 'eradicating' the national language and/or the minority languages and in turn the heritages and cultures of the country concerned. English as a lingua franca indirectly is challenging national languages as it quickly spreads as the global language for communication, markets and education worldwide. The case in Cameroon illustrates this where students although having a choice of entering French or English medium schools and although French is one of the main national languages, are opting more for an English medium education and, in so doing, are finding it a great challenge (Kuchah, 2018).

On another note, and as a reaction to the fact that there would be negative transfer from one language to the next, and in keeping with instructing students to be better prepared in studying in the medium of English, a great deal of research has been carried out in different paradigms. This research includes studies such as English for Academic Purposes (EAP), English for Specific Purposes (ESP), genre writing, English as the medium of instruction (EMI), Integrated Content and Language in Higher Education (ICLHE), the latter being quite a challenge in the cooperation between integrating the content and language by the English and Content instructors (see Schmidt-Unterberger, 2018). The purpose of this research has been to offer teachers instructional models to initiate students into academic English in the different disciplines based on the assumption that writing the 
various genres in the disciplines differ in which teachers need to instruct their students and thus avoid codeswitching which could empede the learning of the target language (see Bahous et al., 2013 for the controversy).

To investigate this in the Lebanese context, a study, carried out in one English medium university in Lebanon, (Bacha, 2018), indicated students perceive having no significant negative transfer from Arabic or French in writing in English. Interestingly, also, students viewed expecting grades of over $80 \%$ on their essays and noted that the organization, vocabulary and grammar when writing essays in English did not pose any problems. These results were contrary to the actual essay assessments through content analysis that indicated L1 negative interference and confirmed research in the field (Kaplan, 1966; Grabe \& Kaplan, 2006; Purves, 1988). The implications of these results suggest along with the genre and EAP studies that instruction is necessary which would help students improve their academic writing (Hyland, 2006; Paltridge, 2004; Swales, 1990). The assumption is also that if students are instructed in academic English, then they would better succeed in EMI in their education and thus not need a bilingual education.

Nevertheless, English as the sole medium of instruction at pre and university levels has been questioned as to its efficiency and quality in the age of globalization. During the late 19th century and throughout the 20th century, especially after the 1960's with increased immigration to Europe and the United States, many schools worldwide are rising to the challenge of including home languages such as Spanish, German, Italian, in which some content subjects are taught (Gandara \& Escamilla, 2017). This inclusion, referred to as transitional bilingual education (TBE), English still remains the main medium of instruction, but other languages are emerging. At the universities, though, content subjects to date are taught in one language to a large extent, mainly English or the home language (Gandara \& Escamilla, 2017).

Recently, however, Dearden (2016 among others) noted that in a study carried out on 55 Western and Eastern countries that, although students and instructors favored EMI, more prevalent in private institutions though, they would prefer having the national language along with English and thus bilingual education.

However, drawing on bilingual theory noted above, the implications seem to counter the emphasis on EMI on the students' success in education. The Western model of higher studies in today's world does emphasize critical thinking, problem solving, and application of knowledge in new situations, negotiation and other high order cognitive skills which would be provided in English as a medium of instruction (EMI) following a western curricula model and which is not offered by many national languages that depend upon traditional methods and memorization. But it would be an added advantage for students to be exposed to two or more languages in pre and university education with the implication that they would excel over their counterparts who studied in the medium of one language or spoke only one language at home. It would also be an advantage to continue this bilingual education in higher institutions where they would be more competitive as they transition into their careers and the global market. The languages of instruction would then depend upon the languages spoken in a given country.

While two languages as the medium of instruction has not met with much positivism in some higher education institutions, it has in others, such as in Finland where courses are taught in Finnish, and/or Swedish and English, (Anckar, 2006; Källkvist \& Hult, 2014), and in Switzerland and Freiburg. Langner and Imbach (2000) note a few possible models:

On the one hand, there are clearly defined and quantified diplomas; on the other hand, the choice of attending several courses in the second language, but of taking examinations in the primary language. Between the two extremes - the definition of bilingual diplomas on the one hand and several special courses on the other - there is a wide range of ways to achieve academic bilingualism. Finally, basic principles for the operation of a multilingual university are proposed (p. 461).

Cummins (2000) mentions that the learning of concepts in the second language is 'easier' when they have learned them in their first or home language and encourages the use of L1 along with L2 in their education. Arzoz (2012) reports on two languages in higher education such as "French and Dutch in Belgium, German and French in Switzerland, English and French in Canada" (p. 1).

In today's world, the balance seems to be tipping more towards the value that a bilingual education provides. A statement made by Professor Stephen May, an advocate of bilingual education, on September 15, 2017 to the New Zealand Herald is indicative of the effort made to influence parents in giving their children a bilingual education considered to be beneficial.

Bilingual and immersion programmes, like Maori-medium education, are highly effective but there's a lot 
of scaremongering out there about them, and some widely held and very entrenched negative attitudes about bilingualism and bilingual education.

Doiz, Lasagabaster and Sierra (2013) mention that with increasing international study programs, English medium universities have grown worldwide but are rising to the challenge by having integrative learning in the classroom where the home language has been successfully used for better communication among the students coming from immigrant families. Archila and Truscott de Mejía (2017) discuss the education in university science courses in a Colombian university. They found that the majority of the professors indicated positive views towards a Spanish-English bilingual education in today's internationalization of science. However, it is not without its challenges as the language of instruction for teaching and research. Furthermore, a study carried out in South Africa (Madiba, 2010) described a situation in which more than one language was used as the medium of instruction in an institution of higher learning, which gave more opportunities for students to follow higher studies. They could either study in one medium or choose to study in two. Also, students who spoke a language other than the one that had been the only medium of instruction at the university, could now have a university education.

Plessis (2006) notes in this debate that bilingualism as the medium of instruction in South Africa in higher education is 'flexibile' implying its effectiveness, and notes three types: Dual-Medium Education (DME), Parallel-Medium Education (PME) and English-Medium Instruction (EMI) where two languages are given in separate classes or two languages are given in the same class as is the case in Sweden (Källkvist \& Hult, 2014). However, the author does qualify that this is by no means a move to bilingual education at the university as the main reason for introducing these paradigm methods of instruction is more for home language maintenance and its survival which is tradition and cultural-based. In fact, the complexity of more than one language as the medium of instruction has brought about misconceptions and misunderstandings about its meaning. Despite this, controversies surrounding the goal and/or value of a bilingual education has had its toll in the United States, Britain and Canada (see Edwards, 1980; Edwards \& Redfernm, 1992). But this should not dissuade institutions to consider the possibility of a bilingual education and its benefits. Importantly, another bilingual education university in Canada is described where the benefits to student learning out weight the disadvantages (Beillard, 2000).

The University of Ottawa ... as a bilingual university was reaffirmed, together with its special mission of preserving and developing French culture in Ontario. ... has moved toward "institutional" bilingualism and has placed a strong emphasis on the parallel offering of programmes. It ... has delivered positive results ( $\mathrm{p}$. 469).

\subsubsection{Language Background in Lebanon}

It is important to mention the language background in Lebanon in order to appreciate the multilingual/cultural wealth of the country and consequently the challenges faced in reaping this wealth in offering the best learning language tools. The past decade has seen many English medium universities mushrooming in Lebanon, but often noted by high ranking universities that they lack good standing in teaching, technology, and curriculum development (personal communication with some administrators in accredited universities).

Although English is not the official language in Lebanon, it is the medium of instruction in the majority of private pre and university institutions and a second or third language in governmental public educational institutions (Esseli, 2017). Over the past century and due to the influence of the French and American missionaries and colonialism in Lebanon, there have been different models of bilingual education in Lebanese schools. Arabic remains the official national language, and although many languages are spoken such as Spanish, German, Armenian; English and French remain the main ones. Attitudes of students show they prefer to study in English and/or French rather than Arabic as they see the former two a pathway to a better life and higher studies (Diab, 2006; 2009). In 1994, the Lebanese Ministry of Education made it mandatory that, in addition to Arabic, all public high schools teach all subjects in a second language as the medium of instruction, and teach a third additional foreign language with an intercultural/cultural component and based on recent methodologies.

In Lebanon, all high schools have either French and/or English as the medium of instruction and the other as a third language. Arabic is only taught in Arabic language classes. The students then are referred to as either English educated or French educated. Thus, students then need to apply to a university in which English (EMI) and/or French (FMI) is the medium of instruction depending upon which (or both) of these two languages was their MI at the pre-university level. Since many students are bilingual, trilingual or multilingual, why not offer content courses in both languages or have a similar course, one given in English and one in French.

This profile clearly reflects the country's bi/multilingualism/culturalism (see Esseili, 2017; Orr \& Annous, 2018; 
Shaaban \& Ghaith, 1997 for the history of the languages in Lebanon). Although some researchers, teachers and administrators have followed the progress of the educational mandate of 1994 at the pre-university levels in public and some private schools (see Sbaity, 2010; Shaaban, 2013), there are few or no studies, to the author's knowledge, on students' viewpoints of a bilingual education in the Lebanese context. There are even fewer at the university level.

Orr and Annous (2018) indicated that students favored learning in English and French and not the national language Arabic. Arabic is not viewed by students as prestigious as English and French are and which are viewed as passports to continue their higher studies in preferred Western type institutions.

Students in Lebanon have the choice to take their subject courses in either French or English or a mixture at the high school level. Although there are high schools and universities that follow these models, it is not a usual practice at the university level in Lebanon. Most private universities have one language as the medium of instruction. Often students travel abroad, mainly to the United States, United Kingdom, Canada, Australia, or Europe to follow their higher education in English or French as some do not find the opportunities in their home country.

Esseli (2017) further notes that there are forty-one private universities and one state university in Lebanon: the Lebanese University (LU). From the forty-one, thirty-two are full universities while the remaining are colleges or religious affiliated. According to her, most of the 'full universities' ten, currently, have only English as the medium of instruction and are private universities, eight have English and French, also private universities, four English and Arabic, and six, Arabic, English and French. The Lebanese Government University offers its academic programs in Arabic and others in French and English, while still others only in French which give opportunities to students to further their studies in the language they prefer, and more importantly, to do so in the language they can. Although no study has been made on the effectiveness of this on student learning, it has made it possible for more students in Lebanon to continue on to higher education where they can exploit their biliteracy (Bahous, Bacha, \& Nabhani, 2012; Shaaban \& Ghaith, 1997).

Related to these bilingual studies is code switching research which indicates that in using English as the medium of instruction (EMI) and using L1 for practical, cultural, communicative and management purposes, also aids in learning (e.g., Bahous, Nabhani, \& Bacha, 2013; Cahyani, Courcy, \& Barnett, 2016). A study carried out in Kuwait (Alghasab, 2018) with L1 Arabic and L2 English in the classrooms found positive results in learning and notes that a bilingual education impacts curriculum design, classroom management and interpersonal relationships. Most bilingualism as the medium of instruction implementation worldwide, though, has been at the pre-university levels. Although there are universities that offer some programs in either the home language and/or in English, they are very few (Arzoz, 2012).

In this context, recent sociolinguistic research in translanguaging has indicated that using the bi/multi-literacy of the students in bilingual classrooms can give positive results. The students interact in given tasks which help them accomplish the tasks efficiently and acquire new knowledge in educational contexts. This is contrary to some other researchers who see other languages in the classroom as interfering factors (see for example Creese \& Blackledge, 2010; Duarte, 2016; Moodly, 2007). These researchers define translanguage as the

act performed by bilinguals of accessing different linguistic features or various modes of what are described as autonomous languages, in order to maximize communicative [speech]... [and] describe translanguaging as both an act of bilingual performance and a pedagogical approach for systematically teaching multilinguals, by encouraging them to use the totality of their language knowledge to engage in educational learning (Duarte, 2016, pp. 1-2).

They found that translanguage helped in communicative speech tasks and on tasks in mainstream educational pre-university content classes in focusing on the functions of multilingual repertoires for negotiating and acquiring knowledge in mainstream education. Some examples of these functions are paraphrasing, quoting, describing, problem-solving, hypothesizing, and debating, all higher order cognitive skills required of students at the university level and in the work place.

These results contradict the beliefs that there is negative interference from L1 and afford counterarguments to monolingual supporters.

These are very valuable results for the present study to explore the possibility of bilingualism as the medium of instruction irrespective of the model that is to be selected (Van Der Wildt et al., 2015). The results of this study suggest that allowing translanguaging in phases of collaborative talk may be one feature of such a pedagogical shift (Duarte, 2016). 
The aim of the present study is to obtain the views of students on a bilingual education and to compare these views to those of their teachers in an English medium private university in Lebanon.

The three research questions are mentioned below:

Research question 1: What significant differences are there between student and teachers' preferences for bilingualism as the medium of instruction at the pre and university levels?

Research question 2: What significant differences are there between EMI and FMI students' preferences for bilingualism as the medium of instruction at the pre and university levels?

Research question 3: What significant differences are there between the genders' perceptions for bilingualism as the medium of instruction at the pre and university levels?

\section{Methodology}

This study focused on administering a survey to first year university students and their teachers to explore their views as to the medium of instruction they would prefer at pre and university educational levels.

\subsection{Participants}

The participants comprised a purposive representative sample of $215 \mathrm{~L} 1$ speakers of Arabic first year university (used interchangeably with tertiary in the present study) students attending the first of four required English language academic writing courses at an English medium of instruction (EMI) private university in Lebanon. They were placed in the English courses according to their TOEFL or the university's English Entrance Exam placement scores. These participants were selected as they had just completed their last year in high school, and thus had fresh experience with the MI used in their schools and could best give feedback on the survey used in this study. The demographic profile showed that there were $58.06 \%$ males and $49.04 \%$ females, a total of $58.06 \%$ from French medium of instruction (FMI) high schools (used interchangeably with pre-university in the present study), 36.06\% from English medium of instruction (EMI) high schools, and 1.08\% from other mediums of instruction (OMI) such as French/English, Armenian, Spanish or Arabic. The participants were a representative sample of the various university majors with $29.03 \%$ in Engineering, $17.20 \%$ in Business, $13.98 \%$ in Pharmacy, $9.68 \%$ in Architecture and the remainder of $39.79 \%$ distributed almost equally among Nursing, Biology, Computer Science, Political Sciences, Nutrition and undeclared majors. There were $77.42 \%$ Lebanese nationals, with the remainder $20.58 \%$ dual nationalities of Lebanese with Spanish, American, French, Venezuelan, Australian, Yemeni, Russian, Serbian, Nigerian, Jordanian, Syrian, Palestinian, Canadian, or Argentinian and some with three nationalities such as Lebanese, Armenian and American. There were a few with only one nationality such as American or Canadian or British and since they were not bilingual, they were excluded from the study. The selected sample also showed that they could speak the languages of their home country. This information was obtained to show the $\mathrm{bi} / \mathrm{multi} /$ lingual/cultural characteristic of Lebanon which may impact the choice of language(s) used as the medium of instruction in educational institutions.

Five female and two male teachers participated in the study, L1 Arabic speakers of English and holders of a Masters of Arts Degree in English or Teaching English as a Foreign Language (TEFL). Their ages ranged from thirty to fifty years old, and each had between ten to twenty-five years of teaching experience. The student and teacher sample were found satisfactory for the present study.

\subsection{Survey}

Two parallel surveys were constructed by the researcher for both students and their teachers on preferences toward bilingualism as a medium of instruction at both the pre and university levels. Each of the two surveys had eight questions; the first four questions focused on the respondents' preferences for English, French, Arabic or English/French at the high school level. The second four questions focused on the respondents' preferences for English, French, Arabic or English/French at the university level (Refer to Appendices A and B for the student and teachers' questionnaires). A likert scale from 1 to 5 was used with 1 (never) being representative of the lowest preference and 5 (always) of the highest. Below is a sample question, the first for the student and the second the teacher.

\begin{tabular}{|c|c|c|c|c|c|c|c|}
\hline $1=$ Never & $2=$ Rarely & $3=$ Sometimes & $4=$ Most of the time & \multicolumn{2}{|c|}{$5=$ Always } & & \multirow[b]{2}{*}{5} \\
\hline 1 & I like to study all $\mathrm{m}$ & jects only in Eng & $\mathrm{h}$ in high school & 2 & 3 & 4 & \\
\hline $1=$ Never & $2=$ Rarely & $3=$ Sometimes & $4=$ Most of the time & \multicolumn{2}{|c|}{$5=$ Always } & & \\
\hline
\end{tabular}




\subsection{Procedure}

A pilot study was carried out on 25 students in one first academic English class in order to check for any concerns in clarity and content. The survey was then refined to reduce any ambiguities in meaning and language. The survey was then administered in class by the teachers in the first required academic English course to five hundred students ( 25 students on average per class) at the university where the study was carried out at the time of the study. The pilot class was excluded to avoid any subjectivity in answering the questions twice. A response rate of $215,42 \%$ was obtained. Teachers responding to a parallel survey were seven out of 15 giving an approximate $50 \%$ response rate. Ethical considerations were accounted for in receiving approval from the Institutional Review Board (IRB) at the university where the study was conducted, and the surveys were kept voluntary, anonymous and confidential.

\subsection{Data Analysis}

The survey data was input into the Statistical Package of Social Sciences (v.22) and a quantitative analysis of the data was carried out. Since the teachers' sample was small and did not show normality, comparative non parametric Kruskall Wallis statistical testing was carried out for means of two independent samples and Spearman significance test at a two-tailed significance level of less than $p=0.05$ between the two samples. This was done to find any significant differences in preferences for bilingualism as a medium of instruction according to three independent variables 1) student and teachers, 2) English (EMI) and French (FMI) educated students, and 3) bi/multilingual female and male students.

\section{Results, Data Analysis and Discussion}

The results, analysis and discussion are given according to the three research questions.

\subsection{Research Question 1: What Significant Differences Are There Between Student and Teachers' Preferences for Bilingualism as the Medium of Instruction at the Pre and University Levels?}

Data analyzed according to means in Tables 1 and 2 indicate that both student and teachers show they prefer English first (means between 4 to 4.2), a combination of French and English second (means between 1.7 to 2.6), French third (means between 1.7 to 2.5) and lastly Arabic (means between 1.1-1.6) as the medium of instruction at the high school and university levels.

Table 1. Mean student preferences for medium of instruction

\begin{tabular}{lll}
\hline $\mathrm{N}=215$ & Mean & Std. Deviation \\
\hline English high school & 3.4093 & 1.25672 \\
French high school & 2.5953 & 1.53129 \\
Arabic high school & 1.5794 & .91966 \\
English \& French high school & 2.6589 & 1.34635 \\
English university & 4.2465 & .93712 \\
French university & 1.9484 & 1.16642 \\
Arabic university & 1.3981 & .81228 \\
English \& French university & 2.4372 & 1.34460 \\
\hline
\end{tabular}

Table 2. Mean teacher preferences for medium of instruction

\begin{tabular}{lll}
\hline $\mathrm{N}=7$ & Mean & Std. Deviation \\
\hline English high school & 3.7143 & 1.60357 \\
French high school & 2.0000 & .81650 \\
Arabic high school & 1.1429 & .37796 \\
English \& French high school & 3.5714 & 1.27242 \\
English university & 4.0000 & 1.15470 \\
French university & 1.7143 & .75593 \\
Arabic university & 1.2857 & .75593 \\
English \& French university & 3.0000 & 1.26491 \\
\hline
\end{tabular}

Data analyzed according to Spearman significance statistical test in Tables 3 and 4 indicate that there are no significant differences ( $\mathrm{p}$ is greater than 0.5 ) between student and teacher views on what they prefer the medium of instruction to be at both the high school and university levels.

However, teacher results show a very high mean preference for a bilingual education in English and French and higher than those of the students at both the high school and university levels. English remains the highest mean 
preference for both students and teachers at both the high school and university levels.

Table 3. Mean rank preferences for medium of instruction in high school and university between students and teachers

\begin{tabular}{lll}
\hline & Student or Faculty & Mean Rank \\
\hline English high school & Student & 110.87 \\
& Teacher & 130.93 \\
French high school & Student & 112.08 \\
\multirow{2}{*}{ Arabic high school } & Teacher & 93.57 \\
& Student & 111.86 \\
English \& French high school & Teacher & 84.64 \\
& Student & 109.69 \\
English university & Teacher & 151.07 \\
\multirow{2}{*}{ French university } & Student & 111.91 \\
\multirow{2}{*}{ Arabic university } & Teacher & 98.93 \\
\multirow{3}{*}{ English \& French university } & Student & 110.63 \\
& Teacher & 106.50 \\
& Student & 109.80 \\
& Teacher & 100.36 \\
& Student & 110.22 \\
& Teacher & 139.00 \\
\hline
\end{tabular}

Table 4. Significant differences between students and teachers

\begin{tabular}{|c|c|c|c|c|c|c|c|c|}
\hline & $\begin{array}{l}\text { English } \\
\text { High } \\
\text { school }\end{array}$ & $\begin{array}{l}\text { French } \\
\text { High } \\
\text { School }\end{array}$ & $\begin{array}{l}\text { Arabic } \\
\text { High } \\
\text { School } \\
\end{array}$ & $\begin{array}{l}\text { English \& } \\
\text { French High } \\
\text { School }\end{array}$ & $\begin{array}{l}\text { English } \\
\text { University }\end{array}$ & $\begin{array}{l}\text { French } \\
\text { University }\end{array}$ & $\begin{array}{l}\text { Arabic } \\
\text { University }\end{array}$ & $\begin{array}{l}\text { English \& } \\
\text { French } \\
\text { University }\end{array}$ \\
\hline Chi-Square & .691 & .606 & 1.687 & 2.999 & .329 & .034 & .273 & 1.262 \\
\hline Df & 1 & 1 & 1 & 1 & 1 & 1 & 1 & 1 \\
\hline Asymp. Sig. & .406 & .436 & .194 & .083 & .566 & .854 & .601 & .261 \\
\hline
\end{tabular}

Note. a. Kruskal Wallis Test, b. Test Statistics.

These results are enlightening. Most of the students find English more prestigious (personal communication with a wide sample of students at the university in the present study) as it opens more opportunities for study and jobs abroad. Arabic, the national language, is ranked the lowest as students cannot compete with jobs in the global market of today without a second and/or a third foreign language. This result confirms previous research in the field where Arabic was also found less prestigious and English or French seen as a ticket to a better future abroad (Diab, 2006, 2009; Orr \& Annous, 2018). Furthermore, a bilingual education would allow for more opportunities and better achievement levels (Alghasab, 2018).

There is a small percentage of students and teachers who prefer only Arabic which is in line with those countries that want to keep their national language alive (Gandara \& Escamilla, 2017; Suleiman, 2003). It is interesting to note, however, that a good number of students and teachers are strongly in favor of a bilingual education of English and French at the university level which confirms previous research that students find these Western languages prestigious and a career path over the national and minority languages (Zakharia, 2009).

\subsection{Research Question 2: What Significant Differences Are There Between EMI and FMI Student Preferences for Bilingualism as the Medium of Instruction at the Pre and University Level?}

It was interesting to explore the EMI and FMI student preferences for bilingualism as the medium of instruction in high school since they had just completed their secondary education and were entering university. The researcher found it relevant to tap their past experience at this stage.

Findings indicated that approximately $70 \%$ of the French educated students preferred French as the medium of instruction and then approximately $30 \%$ English in high school (Figures $1 \& 2$ ), while approximately $90 \%$ of the English educated (EMI) preferred English as the medium and approximately 10\% preferred French. Significance testing using the Pearson statistical testing for normal student data distribution indicated high significant differences between EMI and FMI students $(\mathrm{p}=0.000)$. 


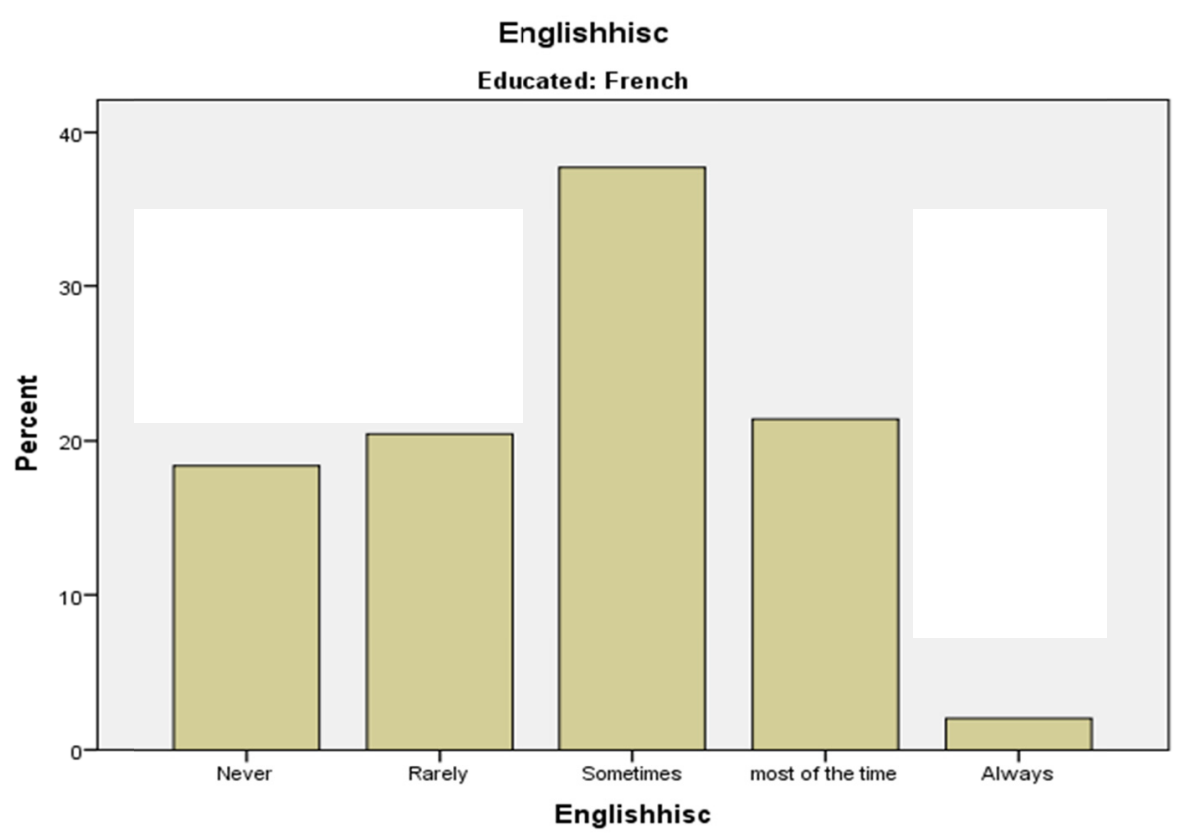

Figure 1. French educated students' views for English as the medium of instruction in high school

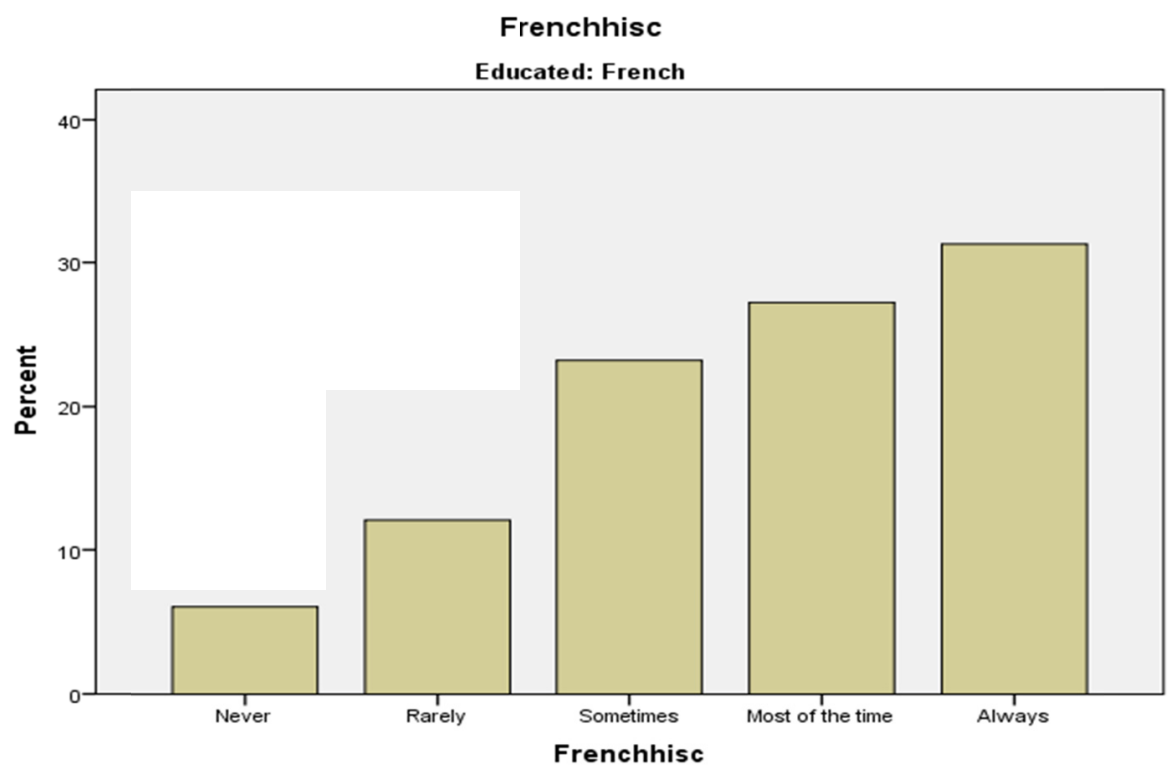

Figure 2. French educated students' views for French as the medium of instruction in high school

Furthermore, the French educated students indicated a low preference for Arabic as the medium of instruction in high school (Figure 3), while the English educated showed a lower preference. There were no significant differences between the two groups ( $\mathrm{p}=$ greater than 0.5$)$.

The French educated students (approximately 75\%) indicated, however, a preference for a bilingual education of both French and English (Figure 4). The English educated students, in contrast, showed less of a preference (approximately 65\%) for a bilingual education but preferred English to be the medium of instruction over a bilingual one. Significance testing using the Pearson statistical test for normal student data distribution indicated no significant differences between EMI and FMI students $(p=$ greater than 0.5$)$ on bilingualism as the medium of instruction in high school. 
These findings confirm the studies in the literature where English is the preferred medium of instruction and confirms the results of the comparative student and teacher statistics in the present study (e.g. Orr \& Annous, 2018)

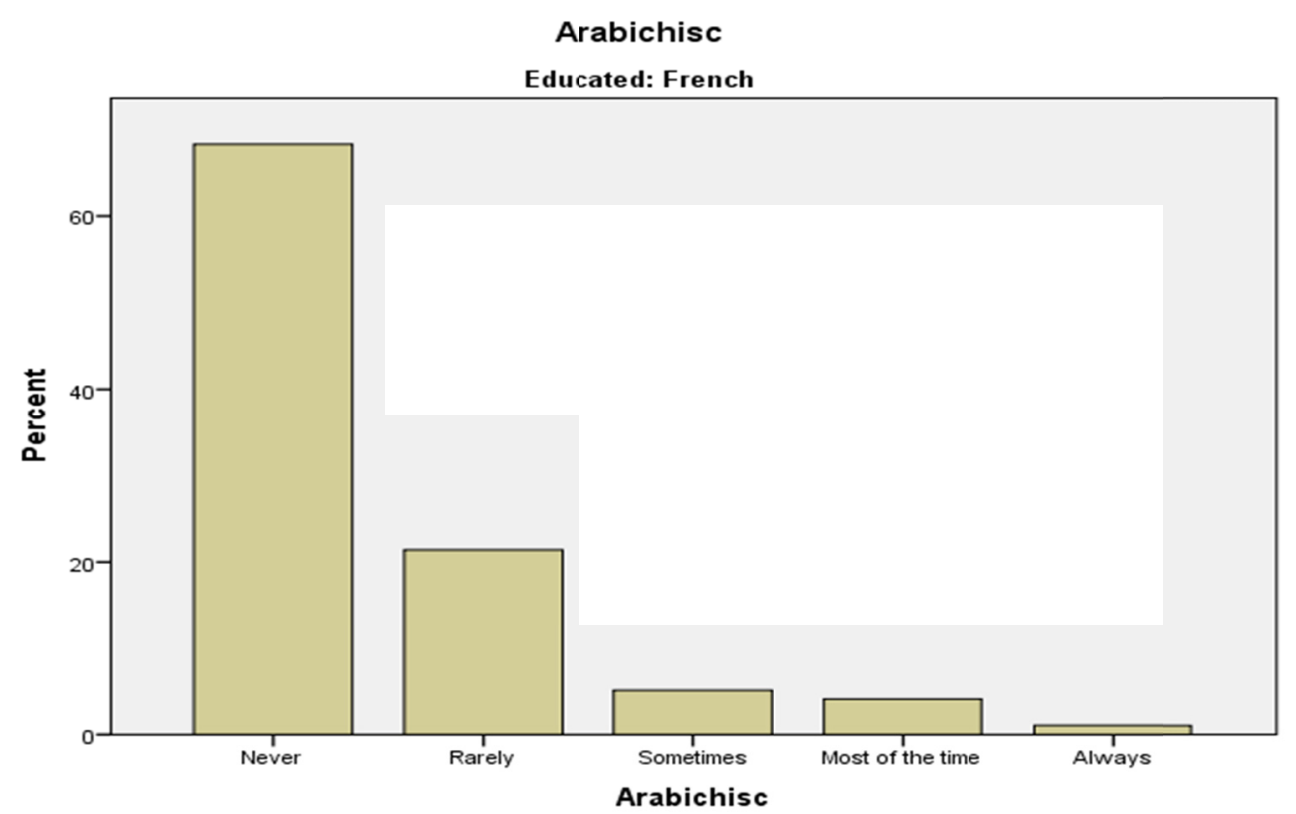

Figure 3. French educated students' views of Arabic as the medium of instruction in high school

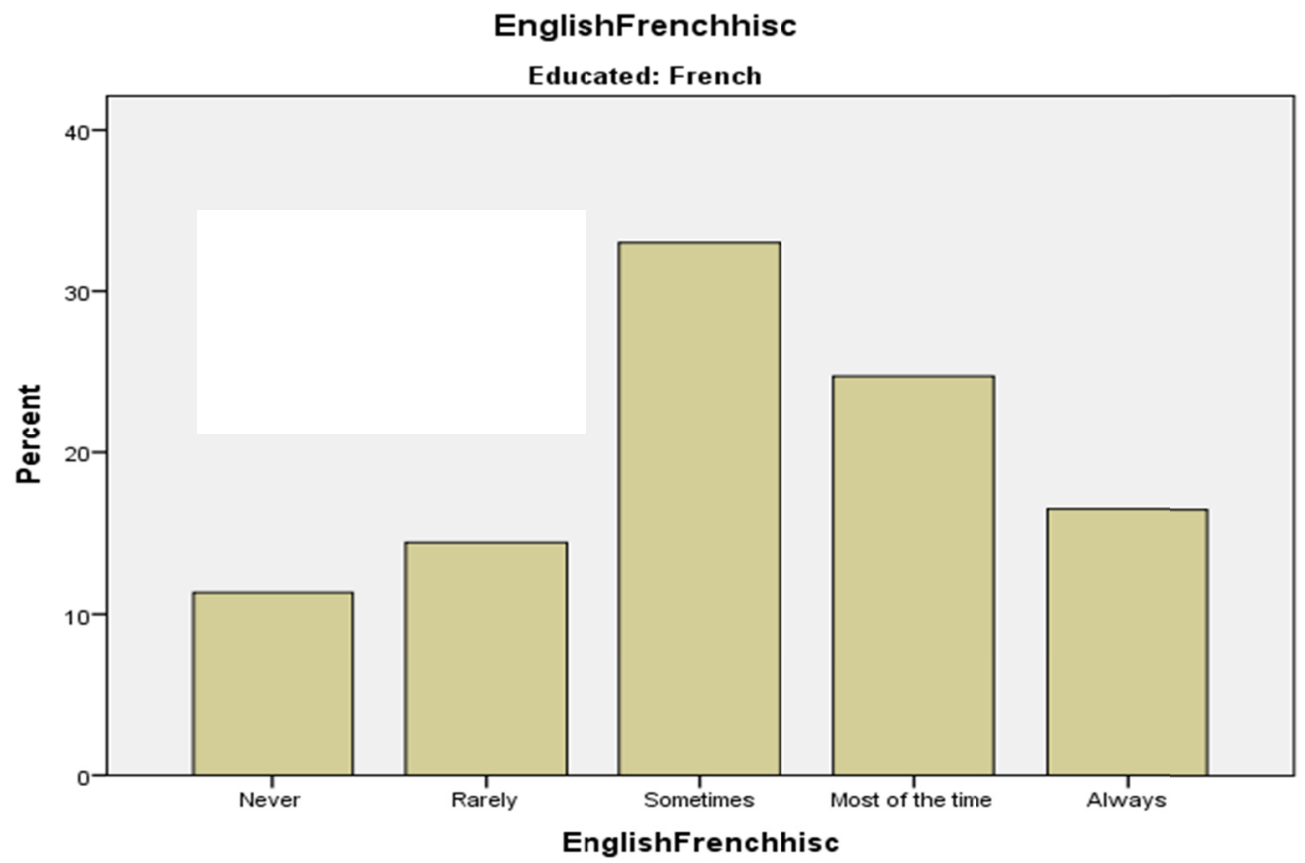

Figure 4. French educated students' views of English and French as the mediums of instruction in high school

Given that English has become the lingua franca for business and world communication, this result is again not surprising. It is interesting though students do not favor Arabic, the national language, as the medium of instruction and also confirms the results above in this study (e.g. Diab, 2006, 2009). There does seem, however, a preference 
for bilingualism as the medium of instruction using English and French in high school from both EMI and FMI students. Comparing the results between research questions 1 and 2, although the French educated students in high school preferred French as the medium of instruction in high school, the question is what percentage of these FMI students preferred English out of the high mean of 4.2 and how many preferred a bilingual education of English and French out of the mean of 2.4 (see Table 1) when asked for their preferences on the medium of instruction they preferred at the university level, and what factors changed their preferences if any. This needs future research studies.

The results according to MI here have implications for language policies in educational institutions which have, it would seem, a dual role in 'restoring' the place of the national language to keep the heritage, culture and identity of its people, but at the same time consider offering students a bilingual education. (Orr, \& Annous, 2018).

\subsection{Gender}

Research question 3: What Significant Differences Are There Between Male and Female Student Preferences for Bilingualism as the Medium of Instruction at the Pre and University Levels?

Gender studies have shown controversial findings based on achievement levels in learning languages (e.g., Glowka, 2014). Although, this is not the main focus of the present study, it was also found interesting to do a preliminary exploration which would add knowledge to the field and could lead to further studies.

Data analysis according to mean differences in Tables 5 and 6 indicate that females significantly prefer a bilingual language instruction $(\mathrm{p}=.000)$ than do males at both the high school and university levels. However, the mean ranks and the statistical testing for significance show that there are no significant differences in their preferences for EMI in both high school and university. Again, EMI is the preferred MI which confirms the literature in the field that English is indeed a prestigious priority.

Furthermore, the females, according to the findings, preferred more than their male counterparts to study in two languages, French and English, the result being highly significant $(p=.000)$. Why this is so would be part of another study, but to the researcher's experience, females have shown better results in language learning in the context of the study and which other researchers confirm (Glowka, 2014).

There is some agreement in the literature that the genders in learning languages use different strategies and in some circumstances females are higher language achievers (e.g., Chayata \& Sapsirin, 2014; Glowka, 2014; among others). Even though this result cannot be generalized, it does show a light on gender preferences to bilingualism as a medium of instruction.

Table 5. Mean differences between genders as to medium of instruction in high school and university

\begin{tabular}{lll}
\hline & Gender & Mean Rank \\
\hline English high school & Female & 107.62 \\
& Male & 114.35 \\
French high school & Female & 128.93 \\
& Male & 93.55 \\
Arabic high school & Female & 102.99 \\
& Male & 117.75 \\
English \& French high school & Female & 122.00 \\
& Male & 99.41 \\
English university & Female & 113.50 \\
\multirow{2}{*}{ French university } & Male & 108.53 \\
& Female & 125.23 \\
Arabic university & Male & 94.63 \\
& Female & 101.30 \\
English \& French university & 116.63 & 116.63 \\
& Female & 127.23 \\
& Male & 94.07 \\
\hline
\end{tabular}

Table 6. Significant differences between gender preferences for medium of instruction

\begin{tabular}{|c|c|c|c|c|c|c|c|c|}
\hline & $\begin{array}{l}\text { English } \\
\text { High } \\
\text { school }\end{array}$ & $\begin{array}{l}\text { French } \\
\text { High } \\
\text { School }\end{array}$ & $\begin{array}{l}\text { Arabic } \\
\text { High } \\
\text { School }\end{array}$ & $\begin{array}{l}\text { English \& } \\
\text { French High } \\
\text { School }\end{array}$ & $\begin{array}{l}\text { English } \\
\text { University }\end{array}$ & $\begin{array}{l}\text { French } \\
\text { University }\end{array}$ & $\begin{array}{l}\text { Arabic } \\
\text { University }\end{array}$ & $\begin{array}{l}\text { English \& } \\
\text { French } \\
\text { University }\end{array}$ \\
\hline Chi-Square & .649 & 18.219 & 4.050 & 7.318 & .396 & 15.153 & 5.797 & 15.933 \\
\hline Df & 1 & 1 & 1 & 1 & 1 & 1 & 1 & 1 \\
\hline Asymp. Sig. & .420 & .000 & .044 & .007 & .529 & .000 & .016 & .000 \\
\hline
\end{tabular}

Note. a. Kruskal Wallis Test, b. Grouping Variable: Gender. 


\section{Conclusion}

The purpose of the present study is a comparative exploratory investigation into what extent first year university students and their teachers prefer bilingualism as a medium of instruction at both the high school and university levels in the Lebanese context. The study was motivated by what language(s) would be selected in the bi/multilingual profile in Lebanon if the stakeholders (students and their teachers) were given the choice. Three research questions guided the study. The findings indicate that students and teachers agree on a bilingual medium of instruction at both educational levels; English, however, is the favored medium. Arabic, the national language, is not favored by all respondents.

The study does raise important issues for English medium universities in multilingual and multicultural countries such as Lebanon and which were also addressed in the literature.

Certainly, the issue of a bilingual educational has its complexities, but as the literature shows, in spite of this, many universities abroad in addressing these have found it effective to teach in the home/minority language as well as a foreign language such as English or Spanish or French. Considerations have been for more effective student cognitive development (Bartolottie \& Marian, 2012; Bhattacharjee, 2012; Baker \& Wright, 2017; Dooly, 2007; Vygotsky, 1979) and giving the opportunity for students with low English language proficiency to study in pre and university institutions (Marian \& Shook, 2012) and in keeping the national/minority languages and thus their identity within their cultural mileu (Jin \& Cortazzi 1997).

Many universities worldwide have adopted a bilingual medium of instruction (Zakharia, 2017) with teachers from the same cultural background as that of their students for better understanding of how their students learn and awareness of any negative influencing factors from the home language. This is also the case in the Arab world where universities are implementing Arabic and English as a bilingual medium of instruction (Elhami's 2015).

\subsection{Implications}

These exploratory results have strong implications for English medium universities in Lebanon as students transition into higher education from high schools into the university (e.g., Jaumont, 2018) who may not have the required English proficiency to enter an EMI university nor the proficiency to follow their course of study once they enter. There is a concern, also, that students in Lebanon prefer English and/or French as a medium of instruction and look upon Arabic, the national language as 'less' prestigious (Orr \& Annous, 2018). Students' low preference to the use of Arabic in their education as evidenced in the present study leaves much for language policy makers to consider.

The findings in the present study confirm the foregoing which raises much concern as to whether Arabic in education will 'survive' which has wide implications for the 'survival' of Lebanese people's cultural norms and identity. Offering courses in English and/or French and/or Arabic in the universities in Lebanon would not only draw upon the linguistic background of the students and thus facilitate their learning but also strengthen the Lebanese identity and culture similar to those in some of the European, African, and Canadian models where the minority languages are included into the educational system and thus kept alive. The challenge in Lebanon after the Ministry of Education in 1994 made a second language mandatory for public schools is how to keep a balance in the curriculum between Arabic and the foreign languages and how EM university will address how best to draw upon the students' bi/multilingual background.

\subsection{Limitations}

The results in the present study cannot be generalized as a wider student and teacher sample from more institutions in Lebanon need to be obtained to further explore these preferences. Also, the study needs to triangulate the data for reliability. It was not possible to interview the students or teachers at the time as the students fear a testing situation and teachers think that their own language proficiency is being evaluated. Furthermore, given the situation in the country at the time, it is difficult to have easy access to other universities let alone obtain permission to question the students and teachers. Another limitation is that the researcher carried out the study, wrote and piloted the questionnaire, and analyzed the data which might have biased the results. Future studies should be carried out by other teachers to maintain objectivity. Nevertheless, these exploratory findings do show that a bilingual education is to some extent preferred.

\subsection{Recommendations for Future Research}

It is recommended that future research in this area be carried out with a number of universities in Lebanon and a cohort of university students studying in the medium of English and a cohort in the medium of English and French to explore the difference, if any, in academic achievement and successes. Also, studies are needed as to 
what model of bilingual education would best suit the Lebanese context, or contexts where a bilingual education is being considered as the African situation implies. Further studies could focus on gender differences and language learning strategies in the languages that students speak and achievement levels in the languages. The present study indicated that females prefer a bilingual education, while males showed less preference. In addition, there is a need for comparative studies between universities in Lebanon and abroad such as those in Africa, Canada and North America where content subjects are given in L1 in one class and the same subject given in L2 in another. Interesting future studies would be comparing different bilingual systems of education with one language as a medium of instruction in different subjects which may raise awareness on the use of languages in learning.

It is the contention of the author that having universities in Lebanon offer students the choice in which language medium to study is a great challenge for the growing number of English medium universities. In fact, in the global world in which we live, this may be an inevitable situation for these universities to address in the near future. Moreover, as the competition to enter institutions of higher education increases and the need for these institutions to remain competitive the choice of the medium of instruction becomes crucial.

Given the results in this study and the experience of several universities worldwide, a bilingual education is one very relevant solution for pre/universities to consider. In this context, Marian and Shook (2012) highlight the rich experience we gain through knowing languages. Indeed, a bilingual education may be worthwhile considering as the mission in educating students for successful future careers increases on the international arena (Orr \& Annous, 2018).

\section{References}

Alghasab, M. (2018). The Use of Arabic in Kuwaiti EFL Classrooms: An Exploratory Study on the Patterns and Functions of Language Choice. International Journal of Bilingual Education and Bilingualism, 4(1), 1-13. https://doi.org/10.1080/2331186X.2017.1411037

Anckar, O. (2006). University Education in a Bilingual Country: The Case of Finland. Higher Education in Europe, 25(4), 499-506. https://doi.org/10.1080/03797720120037831

Archila, P. A., \& Truscott de Mejía, A. M. (2017). Bilingual University Science Courses: A Questionnaire on Professors' Practices and Espoused Beliefs. International Journal of Bilingual Education and Bilingualism, Online June 2017. https://doi.org/10.1080/13670050.2017.1334756

Arzoz, X. (2012). Bilingual Higher Education in the Legal Context: Group Rights, State Policies and Globalisation Series: Studies in International Minority and Group Rights (Vol. 2). London: Brill Publishers. https://doi.org/10.1163/9789004228061

Bacha, N. N. (2018). L1 in L2 Academic Essays: A Study of L1 Arabic Writers' Views. International Journal of English Linguistics, 8(2), 15-24. https://doi.org/10.5539/ijel.v8n2p15

Bahous, R., Bacha, N., \& Nabhani, M. (2012). Multilingual Educational Trends and Practices in Lebanon: A $\begin{array}{lllll}\text { Case Study. International Review of Education, 57(5), 7479. } & \text { 737 }\end{array}$ https://doi.org/10.1007/s11159-011-9250-8

Bahous, R., Nabhani, M., \& Bacha, N. (2013). Code-Switching in Higher Education in a Multilingual Environment: a Lebanese Exploratory Study. Language Awareness, 23(4), 353-368. https://doi.org/10.1080/09658416.2013.828735

Baker, C., \& Wright, W. (2017). Foundations of Bilingualism and Bilingual Education (6th ed.). Clevedon, UK: Multilingual matters.

Bartolottie, J., \& Marian, V. (2012). Language Learning and Control in Monolinguals and Bilinguals. Cognitive Science, 36, 1129-1147. https://doi.org/10.1111/j.1551-6709.2012.01243.x

Beillard, J. M. (2000). Bilingualism in a Canadian Context: The Case of the University of Ottawa. Higher Education in Europe, 25(4), 469-476. https://doi.org/10.1080/03797720120037804

Belhiah, H., \& Elhami, M. (2015). English As a Medium of Instruction in the Gulf: When Students and Teachers Speak. Language Policy, 14(1), 3-23. https://doi.org/10.1007/s10993-014-9336-9

Bhattacharjee, Y. (2012). Why Bilinguals Are Smarter: The New York Times, Sunday Review.

Cahyani, H., Courcy, M., \& Barnett, J. (2016). Teachers' Code-Switching in Bilingual Classrooms: Exploring Pedagogical and Sociocultural Functions. International Journal of Bilingual Education and Bilingualism, 21(4), 465-479. https://doi.org/10.1080/13670050.2016.1189509 
Creese, A., \& Blackledge, A. (2010). Translanguaging in the Bilingual Classroom: A Pedagogy for Learning and Teaching? The Modern Language Journal, 1(94), 103-115. https://doi.org/10.1111/j.1540-4781.2009.00986.x

Cummins, J. (2000). Language, Power and Pedagogy. Bilingual Children in the Crossfire. Clevedon, UK: Multilingual Matters. https://doi.org/10.21832/9781853596773

Dearden, J. (2016). A report on the Global Phenomenon of EMI: A Bird's Eye View of EMI In 55 Countries. Research. The British Council, 2-34.

Dewaele, J. M., Housen, A., \& Wei, L. (2003). Bilingualism: Beyond Basic Principles. In honor of H. B. Beardsmore. Clevedon, UK: Multilingual Matters. https://doi.org/10.21832/9781853596315

Diab, R. (2006). University Students' Beliefs about Learning English and French in Lebanon. System, 34(1), 8096. https://doi.org/10.1016/j.system.2005.06.014

Diab, R. (2009). Lebanese University Students' Perceptions of Ethnic, National, and Linguistic Identity and Their Preferences for Foreign Language Learning in Lebanon. The Linguistics Journal, 101-120.

Doiz, A., Lasagabaster, D., \& Sierra, M. (2013). English-Medium Instruction at Universities: Global Challenges. Bristol: Multilingual Matters. https://doi.org/10.21832/9781847698162

Dooly, M. (2007). Constructing Differences: A Qualitative Analysis of Teachers' Perspectives on Linguistic and Cultural Diversity. Linguistics and Education, 18(2), 142-166. https://doi.org/10.1016/j.linged.2007.05.001

Duarte, J. (2016). Translanguaging in Mainstream Education: A Sociocultural Approach. International Journal of Bilingual Education and Bilingualism, 21(5), 1-16.

Edwards, J. R. (1980). Critics and Criticisms of Bilingual Education. The Modern Language Journal, 64(4), 409-415. https://doi.org/10.1111/j.1540-4781.1980.tb05213.x

Edwards, V., \& Redfern, A. (1992). The World in a Classroom: Language in Education in Britain and Canada. Clevedon: Multilingual Matters.

Esseili, F. (2017). A Sociolinguistic Profile of English in Lebanon. World Englishes, 36(4), 684-704. https://doi.org/10.1111/weng.12262

Frayha, N. (2004). Developing curriculum as a means to bridging national divisions in Lebanon. In S. Tawil \& A. Harley (Eds.), Education, Conflict, and Social Cohesion (pp. 159-205). Geneva: UNESCO International Bureau of Education. PMid:15387487 PMCid: PMC6148119.

Gandara, P., \& Escamilla, K. (2017). Bilingual Education in the United States. In Bilingual and Multilingual Education, 1-16. Switzerland: Springer International Publishing. https://doi.org/10.1007/978-3-319-02258-1_33

García O., Lin, A., \& May, S. (2017). Bilingual and Multilingual Education. Encyclopaedia of Language and Education (3rd ed.). Springer, Cham. https://doi.org/10.1007/978-3-319-02324-3

Golash Boza, T. (2005). Assessing the Advantages of Bilingualism for the Children of Immigrant Families. International Migration Review, 39(3), 721-793. https://doi.org/10.1111/j.1747-7379.2005.tb00286.x

Grabe, W., \& Kaplan, R. (1996). Theory and Practice of Writing. New York: Longman. PMid:8815984.

Hyland, K. (2006). English for Academic Purposes: An Advanced Resource Book. London: Routledge.

Jaumont, F. (2018). The Bilingual Revolution: The Future of Education is in Two Languages. New York: TBR Books. PMid:30312503

Jin, L., \& Cortazzi, M. (2013). Researching Cultures of Learning: International Perspectives on Language Learning and Education. London: Palgrave. https://doi.org/10.1057/9781137291646

Kaplan, R. (1966). Cultural Thought Patterns in Intercultural Education. Language Learning, 16, 1-20. https://doi.org/10.1111/j.1467-1770.1966.tb00804.x

Kuchah, H. (2018). Early English Medium of Instruction in Francophone Cameroon: The Injustice of Equal Opportunity. System, 73, 37-47. https://doi.org/10.1016/j.system.2017.10.001

Langner, M., \& Imbach, R. (2000). The University of Freiburge: A Model for a Bilingual University. Higher Education in Europe, 25(4), 461-468. https://doi.org/10.1080/03797720120037796

MacmiKällkvist, M., \& Hult, F. M. (2014). Discursive Mechanisms and Human Agency in Language Policy Formation: Negotiating Bilingualism and Parallel Language Use at a Swedish University. International 
Journal of Bilingual Education and Bilingualism, 19(1), 1-17. https://doi.org/10.1080/13670050.2014.956044

Madiba, M. (2010). Towards Multilingual Higher Education in South Africa: The University of Cape Town's Experience. Language Learning Journal, 38(3), 327-334. https://doi.org/10.1080/09571736.2010.511776

Marian, V., \& Shoo, A. (2012). The Cognitive Benefits of Being Bilingual. U.K. Dana Center: Dana Publishers.

May, S. (2017). Professor Stephen May Advocates Bilingual Education. New Zealand Herald.

Moodley, V. (2007). Code-Switching in the Multilingual English First Language Classroom. International Journal of Bilingual Education and Bilingualism, 10(6), 707-722. https://doi.org/10.2167/beb403.0

Orr, M., \& Annous, S. (2018). There is no Alternative! Student Perceptions of Learning in a Second Language in Lebanon. Journal of Language and Education, 4(1), 79-91. https://doi.org/10.17323/2411-7390-2018-4-1-79-91

Palfreymen, D. M., \& Van der Walt, C. (2017). Academic Biliteracies: Multilingual Repertoires in Higher Education. Bristol, Multilingual Matters. https://doi.org/10.21832/9781783097425

Paltridge, B. (2004). Academic Writing. Language Teaching, 37(2), 87-105. https://doi.org/10.1017/S0261444804002216

Plessis, T. (2006). From Monolingual to Bilingual Higher Education: The Repositioning of Historically Afrikaans-Medium Universities of South Africa. International Journal of Bilingual Education and Bilingualism, 5(1), 87-113. https://doi.org/10.1007/s10993-005-5627-5

Purves, A. C. (1988). Writing across Languages and Cultures: Issues in Contrastive Rhetoric. Newbury Park. C.A.: Sage

Rong, M. (2007). Bilingual Education for China's Ethnic Minorities. Chinese Education and Society, 40(2), 925. https://doi.org/10.2753/CED1061-1932400201

Sapsirin, C. V. S. (2014). Gender differences in language learning style and language learning strategies. Indonesian Journal of Applied Linguistics, 3(2), 77-88. https://doi.org/10.17509/ijal.v3i2.270

Sayigh, R. (1965). The Bilingualism Controversy in Lebanon. The World Today, 21(3), 120-130.

Sbaiti, N. (2010). If the Devil Taught French: Strategies of language and learning in French mandate Beirut. In O. Abi-Mershed (Ed.), Trajectories of education in the Arab World: Legacies and challenges (pp. 59-83). New York: Routledge.

Schmidt-Unterberger, B. (2018). The English-Medium Paradigm: A Conceptualisation of English-Medium Teaching in Higher Education. International Journal of Bilingual Education and Bilingualism, 21(5), 527539. https://doi.org/10.1080/13670050.2018.1491949

Shaaban, K. (2013). Disparity Between Ideals and Reality in Curriculum Construction: The Case of The Lebanese English Language Curriculum. Creative Education, 4(12), 28-34. https://doi.org/10.4236/ce.2013.412A2005

Shaaban, K., \& Ghaith, G. (1997). An Integrated Approach to Foreign Language Learning in Lebanon. Language, Culture and Curriculum, 10(3), 200-207. https://doi.org/10.1080/07908319709525252

Shaaban, K., \& Ghaith, G. (1999). Lebanon's Language-In-Education Policies: From Bilingualism to Trilingualism. Language Problems and Language Planning, 23(1), 1-16. https://doi.org/10.1075/lplp.23.1.01leb

Spolsky, B. (1978). A Model for the Evaluation of a Bilingual Education. International Review of Education, 24(3), 347-360. https://doi.org/10.1007/BF00598049

Suleiman, Y. (2003). The Arabic Language and National Identity: A Study in Ideology. Edinburgh: Edinburgh University Press.

Swales, J. (1990). Genre Analysis: English in Academic and Research Settings. Cambridge: Cambridge University Press. PMCid: PMC1664324.

Van Der Wildt, A., Van Avermaet, P., \& Van Houtte, M. (2015). Do Birds Singing the Same Song Flock Together? A Mixed-method Study on Language as a Tool for Changing Social Homophily in Primary Schools in Flanders (Belgium). International Journal of Intercultural Relations, 49, 168-182. https://doi.org/10.1016/j.ijintrel.2015.10.002 
Vygotsky, L. (1978). Mind in Society: The Development of Higher Psychological Processes. Cambridge, MA: Harvard University Press.

Willig, A. C. (1985). A Meta-Analysis of Selected Studies on the Effectiveness of Bilingual Education. Review of Educational Research, 55(3), 269-317. https://doi.org/10.3102/00346543055003269

Zakharia, Z. (2009). Positioning Arabic in schools: Language policy, national identity, and development in contemporary Lebanon. In F. Vavrus \& L. Bartlett (Eds.), Critical Approaches to Comparative Education: Vertical Case Studies from Africa, Europe, the Middle East, and the Americas (pp. 215-231). New York: Palgrave Macmillan. https://doi.org/10.1057/9780230101760_13

Zakharia Z. (2017). Bilingual Education in the Middle East and North Africa. In O. García, A. Lin \& S. May (Eds.), Bilingual and Multilingual Education. Encyclopaedia of Language and Education (3rd ed.). Springer, Cham. https://doi.org/10.1007/978-3-319-02258-1_21

\section{Notes}

Note 1. Nahla Nola Bacha is a Professor of Applied Linguistics/TESOL at the Lebanese American University, Lebanon where she has taught academic English for over thirty years and served for certain periods as chair of the Department of English and assistant dean of the School of Arts and Sciences. She has published internationally in EAP/EPP, academic writing, discourse analysis, bi/multilingualism, and EFL teaching/learning. Being Lebanese/Australian, she is also interested in contrastive analysis. She has presented at European and U.S.A. conferences and is a reviewer for international refereed journals.

Note 2. This research is part of a larger study on bi/multilingualism approved by the university's committee on human subjects where the study was done at the time. This paper is an adaptation of the presentation given at the British Association of Applied Linguistics (BAAL) International Conference in Edinburgh, Scotland 2013 with a travel grant sponsored by the university where the research was done.

\section{Appendix A}

\section{Student Questionnaire}

Dear Student,

This is research on what language(s) you prefer to study in at high school and university. It is voluntary and confidential. Please fill out to the best of your knowledge. Thank you.

\section{Major: Gender: Female Male Nationality(ies)}

\section{Are you French or English educated?}

French French \& English English

Other (specify)

\section{What is your native language(s)?}

Arabic French English Armenian Spanish

Others: (please specify)

\section{Circle the number that best fits your answer}

\begin{tabular}{|c|c|c|c|c|c|c|}
\hline $1=$ Never & $4=$ Most of the time $5=$ Always & & & & & \\
\hline 1 & I like to study all my subjects only in English in high school & 1 & 2 & 3 & 4 & 5 \\
\hline 2 & I like to study all my subjects only in French in high school & 1 & 2 & 3 & 4 & 5 \\
\hline 3 & I like to study all my subjects in both English \& French in high school & 1 & 2 & 3 & 4 & 5 \\
\hline 4 & I like to study all my subjects only in Arabic in high school & 1 & 2 & 3 & 4 & 5 \\
\hline 5 & I like to study all my subjects only in English in university & 1 & 2 & 3 & 4 & 5 \\
\hline 6 & I like to study all my subjects only in French in university & 1 & 2 & 3 & 4 & 5 \\
\hline 7 & I like to study all my subjects in both English \& French in university & 1 & 2 & 3 & 4 & 5 \\
\hline 8 & I like to study all my subjects only in Arabic in university & 1 & 2 & 3 & 4 & 5 \\
\hline
\end{tabular}

(Bacha, N.) 


\section{Appendix B}

\section{Teacher Questionnaire}

Dear Colleague,

This is research into your preferences towards a bilingual education for your students in high school and university. It is voluntary, anonymous and confidential. Please fill out the answers to the best of your knowledge. Thank you.

\section{Highest Degree obtained}

Years of teaching experience:

Nationality(ies):

Gender: Male Female

What is your native language(s)?

Arabic French English Armenian Spanish

Others: (please specify)

\section{Circle the number that best fits your answer}

$1=$ Never $2=$ Rarely $3=$ Sometimes $4=$ Most of the time $5=$ Always

1 I prefer students to be taught subjects only in English in high school

2 I prefer students to be taught subjects only in French in high school

3 I prefer students to be taught subjects in both English \& French in high school school

4 I prefer students to be taught subjects only in Arabic in high school

5 I prefer students to be taught subjects only in English in university

6 I prefer students to be taught subjects only in French in university

2 I prefer students to be taught subjects in both English \& French in university

$8 \quad$ I prefer students to be taught subjects only in Arabic in university (Bacha, N.)

\section{Copyrights}

Copyright for this article is retained by the author, with first publication rights granted to the journal.

This is an open-access article distributed under the terms and conditions of the Creative Commons Attribution license (http://creativecommons.org/licenses/by/4.0/). 